\title{
THE RELATIONSHIP BETWEEN INTELLECTUAL CAPITAL AND INCOME SMOOTHING AND STOCK RETURNS (CASE IN MEDICINAL COMPANIES)
}

\author{
Hamidreza Vakilifard ${ }^{1}$, Masoumeh Sadat Rasouli \\ ${ }^{1}$ The Faculty member of Accounting Department \\ Islamic Azad University-science and research branch \\ Tehran, Iran \\ E-mail: Vakilifard.phd@gmail.com \\ ${ }^{2}$ PhD Student of accounting \\ Islamic Azad University-science and research branch \\ Tehran, Iran \\ E-mail: m.rasouli62@gmail.com
}

\begin{abstract}
This article examines the relationship between intellectual capital, income smoothing and stock returns. We are capturing income smoothing through total accruals. Income smoothing firms have significantly higher abnormal returns around earnings announcement. In the knowledge economy, intellectual capital has become one of the primary sources of competitive advantage for a firm. Given the remarkable shift in the underlying production factors of a business within the new knowledge economy, it is important for firms to be aware of the elements of intellectual capital that would lead to value creation. So we associated relationship between intellectual capital and income smoothing and stock returns. The sample includes 108 firm-year observations from 2006 to 2011. We have used five variables: three variables to measure IC, and two variables to measure stock returns and income smoothing. Initial data analyses were conducted through SPSS. The results of our study showed that there was relationship between physical capital and stock returns but they did not provide support for the positive relationship between structural capital, human capital and firm's financial performance.
\end{abstract}

Keywords: intellectual capital, income smoothing, stock returns, structural capital, human capital

JEL Classification: G17, G32, M41

\section{Introduction}

Income smoothing refers to managers' attempts to use their reporting discretion to "intentionally dampen the fluctuations of their firms' earnings realizations" (Beidleman 1973, 653)1. Existing literature has documented evidence that firms actively engage in income smoothing (Beidleman, 1973; Ronen and Sadan, 1981; Healy, 1985; DeFond and Park, 1997). Surveys conducted by Graham, Harvey, 
and Rajgopal (2005) also show that CFOs have strong preference for smooth earnings paths.

A number of studies have examined the effect of income smoothing on cost of equity, earnings in formativeness, liquidity, and bond rating. For instance, Francis, LaFond, Olsson and Schipper (2004) examine the effect of income smoothing on the cost of equity. They find that income smoothing has a negative effect on the cost of equity, although the effect is weaker than for other attributes of earnings, such as accrual quality.

In the empirical analysis, we construct a measure of income smoothing, the ratio of standard deviation of firms' cash flow to standard deviation of earnings (e.g., Francis, LaFond, Olsson and Schipper, 2004; Leuz, Nanda and Wysocki, 2003; and LaFond, Lang and Skaife, 2007).

Prior research has documented that firms consistently engage in income smoothing activities (Beidleman, 1973; Ronen and Sadan, 1981; Healy, 1985; Hunt, Moyer, and Shevlin, 1995; Chaney, Jeter, and Lewis, 1996; DeFond and Park, 1997). For example, DeFond and Park (1997) find evidence that when a firm's current performance is poor relative to expected future performance, managers tend to smooth income by increasing accruals, i.e., "borrow" future earnings for use in the current period. They also find that when a firm's current performance is good relative to expected future performance, managers choose income decreasing accruals, i.e. "save" earnings for future period. So we want to know wheter intellectual capital is related to income smoothing and also whether intellectual capital has an effect on stock return.

\section{Literature review and hypotheses development}

For investigation we use Value Added Intellectual Capital from the Pulic model.

Pike expresses that Value Added Intellectual Capital measure is included in: Value Added Capital Coefficient (VACA), Value Added structural Capital Coefficient (VAST), and Value Added Human Capital Coefficient (VAHU).

Existing studies have provided evidence that income smoothing is a desirable earnings attribute. For example, Francis, LaFond, Olsson and Schipper (2004) show that income smoothing tends to reduce the cost of equity. Tucker and Zarowin (2006) provide evidence that income smoothing increases the persistence of earnings. However, extant literature is yet to investigate the question: do intellectual capital components affect income smoothing? Our research fills the gap in the existing literature. 
Among various studies that examine the relation between returns and earnings attributes, Subramanyam (1996) shows that the market prices discretionary accruals.

To test the above mentioned hypothesis, we use returns around earnings announcement dates in our empirical analysis. We argue that returns around earnings announcement provide a sharp test for the following reasons. First of all, different from other firm characteristics, such as size and book to market, income smoothing is an earnings attribute that is revealed to investors at earnings announcement. Thus, returns around earnings announcement dates are more efficient measures of whether investors' price earnings attribute such as smoothness. Secondly, by focusing on a short event window it is easier to control for other determinants of returns, such as unexpected earnings shocks.

We construct income smoothing measure by Total accrual Income Smoothing (TA Smoothing). Following Leuz, Nanda and Wysocki (2003), Francis, LaFond, Olsson and Schipper (2004), and LaFond, Lang and Skaife (2007), TA Smoothing is measured by Std(CFO)/Std(NIBE) over the prior six years, with a higher value corresponding to higher income smoothing. CFO is cash flow from operations, and NIBE is net income before extraordinary items.

\subsection{Intellectual capital}

The importance of intellectual capital (IC) has greatly increased in the last two decades (for examples see Bontis, 1999; Edvinsson \& Malone, 1997). Intellectual capital consists of an organization's patents, processes, employees' skills, technologies, and information about customers and suppliers that has been formalized and utilized effectively to create wealth by producing a higher value asset (Stewart, 1997).

Recognizing the most influential elements of intellectual capital on the firm's performance would help organizations have a clearer understanding and better management of the organizational capabilities they possess. It will also help firms to identify which models and indicators are the best predictors of their success (Jamal Aldin Nazari, 2010).

The first and most important step in any kind of measurement is to define the construct to be measured. Hence, the first issue is to identify what intellectual capital is and how the notion has been defined in the literature. After defining the constructs, the reasons for IC measurement are discussed. Until now, the definitions of intellectual capital have been discordant. In recent years, driven by necessity, many individuals and groups from different disciplines have tried to agree on a standard definition for intellectual capital (Edvinsson \& Malone, 1997). 
Stewart (1991) argued that intellectual capital is the existing knowledge in an organization that can be used to create competitive advantage. He defined intellectual material as the aggregate of an organization's patents, processes, employees' skills, technologies, information about customers and suppliers, and old-fashioned experience. He also defined intellectual capital as the intellectual material that has been formalized and utilized effectively to create wealth by producing a higher value asset.

In addition, Edvinsson and Sullivan (1996) defined intellectual capital as knowledge that can be converted into value. Generally, researchers in the field of intellectual capital have divided the concept of intellectual capital into three main constructs (Bontis, Chua, \& Richardson, 2000).

Bontis (1996; 1998; 1999), Roos et al. (1998), Stewart (1991; 1997), Sveiby (1997b), Edvinsson and Malone (1997), Saint-Onge (1996) as well as Edvinsson and Sullivan (1996) among others, have defined intellectual capital as comprised of: human capital (HC), structural capital (SC), and relational capital.

According to Stewart (1997), human capital is "the place where all the ladders start: the wellspring of innovation, the home page of insight" (p. 86). Bontis, Crossan and Hulland (2002) stated that human capital shows the individual knowledge stock of an organization represented by its employees. Bontis (1998) described human capital as the firm's collective expertise to extract the best solutions from the knowledge of its individuals. Bontis (1999) also argued that human capital is important since it is the source of innovation for organizations.

Structural capital is the knowledge that stays in the firm when employees go home for the night (Ordonez de Pablos, 2004; Roos et al., 1998). Therefore, organizations usually have a residual claim on it. Employees provide structural capital for the company and the company is the residual owner of it. However, structural capital comprises all kinds of "knowledge deposits" which are not supported by employees such as organizational routines, strategies, process hand books and databases (Boisot, 2002; Ordonez de Pablos, 2004; Walsh \& Ungson, 1991).

Structural capital deals with the organizational structure and the information systems of an organization can lead to organizational business and intellect. Human capital is the primary factor for structural capital. Structural capital is dependent on human capital, since human capital is a determinative factor of the organizational form (Jamal Aldin Nazari, 2010).

The third main element of intellectual capital is relational capital. It is defined as the ability of an organization to interact positively with business community members to motivate the potential for wealth creation by enhancing human and structural capital (Marti, 2001). Relational capital comprises the knowledge 
embedded in all the relationships an organization develops, whether it is with customers, competitors, suppliers, trade associations or government bodies (Bontis, 1999).

One of the main categories of relational capital is usually referred to as customer capital that denotes the "market orientation" of the organization. Relational capital includes relationships not only with customers but also with a wide variety of external stakeholders (Jamal Aldin Nazari, 2010).

\subsection{Existing Theories of IC measurement}

The measurement of intellectual capital as a way to assess a company's intangible assets is well accepted both in academia and practice. A review of the literature indicates a mounting number of studies on IC measurement. However, the measurement of intellectual capital is still in an exploratory stage. There is no consensus on a general measurement approach or coherent measurement theory for intellectual capital. The involvement of researchers from different disciplines such as accounting, economics, finance, strategy, human resources and psychology has led to the multidimensionality of IC measurement using different theories to investigate how to measure IC (Jamal Aldin Nazari, 2010).

\section{Measurement theory}

The Value Added Intellectual Coefficient ("VAIC"), developed by Ante Pulic, is an analytical tool for measuring the performance of a company (Pulic, 2000; Van der Zahn et al. 2004). It is based on the assumption that measuring and developing the value adding of a company may have an effect on the company's market value. The connection has also been studied empirically among 250 randomly chosen Financial Times Stock Exchange companies and Vienna Stock companies (see e.g. International Business Efficiency Consulting, 2003; Pulic, 2000). According to the above-mentioned studies, there is a close relationship between the value creation efficiency of the resources, i.e. VAIC, and the market value of companies.

In particular, VAIC measures the total value creation efficiency in the company. The subordinate concept of VAIC, Intellectual Capital Efficiency (ICE), describes the efficient use of Intellectual Capital within a company. This method is built on the premise that value creation is derived from two primary resource bases: physical capital resources and intellectual capital resources. Actually, VAIC indicates the total efficiency of value creation from all resources employed, and ICE reflects the efficiency of value created by the intellectual capital employed. The better a company's resources are utilized, the higher this company's value creation efficiency will be (see e.g. Pulic 2000; Van der Zahn et al. 2004). 
The execution of this method is quite simple. Data needed for the calculation can be found in the official financial statements of the firms analyzed. As already mentioned, the method is based on two resources: capital employed (CE) and intellectual capital (IC). Both resources play a significant role in the value adding of a company and are considered investments. Capital employed consists of equity, the accumulation of profit-adjusting entries, and liabilities with interest. IC consists of human and structural capital (defined this way in the context of VAIC). The phases by which the method is executed are described in the next paragraph (L.L.C, 2002; 2003; Pulic, 2002; 2004). The basic proposition is that the higher the VAIC and ICE, the better has the management utilized the existing potential in the resources employed in creating value (Van deer Zahn et al., 2004). Thus, VAIC considers different efficiency factors related to IC and, in doing so, evaluates how effectively an organization's IC adds value to the organization. As for the Calculated Intangible Value, the VAIC figure is comparable among companies and it can be reported to external stakeholders (Antola et al., 2005).

The formulae for the evaluation of the components of the model are:

- $\quad$ Output $=$ Gross Income.

- $\quad$ Input = Operating Expenses (excluding personal costs).

- $\quad$ Value Added = Output-Input.

- $\quad \mathrm{HC}=$ Personnel Cost, viewed as an investment.

- $\quad \mathrm{CE}=$ Capital Employed (both physical and financial capital). Physical Capital is included in net book value total asset.

- $\quad \mathrm{SC}=\mathrm{VA}-\mathrm{HC}$ (an appropriate proxy for structural capital), a result of human

- Capital's past performance.

- $\quad \mathrm{HCE}=\mathrm{VA} \div \mathrm{HC}$ (Indicator of human capital efficiency).

- $\quad \mathrm{CEE}=\mathrm{VA} \div \mathrm{CE}$ (Indicator of capital employed efficiency).

- $\quad \mathrm{SCE}=\mathrm{SC} \div \mathrm{VA}$ (Indicator of structural capital efficiency)

- $\quad$ VAIC $=$ HCE + CEE + SCE (Value Added Intellectual Coefficient).

VAIC does not consider expenditures on employees as a part of INPUT. This denotes that expenses related to employees are not treated as costs but represent an investment. Consequently, human capital efficiency (HCE) is calculated as follows:

Structural capital cannot be measured directly but is the residual from value added minus human capital. Based on the above calculation, structural capital efficiency (SCE) is: Intellectual capital efficiency (ICE) calculated as the sum of the partial coefficients of human and structural capital. 
This analysis is based on the assumptions that both physical and intellectual capitals are used in production. They are both investment items and are treated as functions of value added creation.

As it was discussed earlier, some studies (for examples see McPherson \& Pike, 2001; Pike \& Roos, 2004) applied measurement theory to the assessment of IC. Elements of measurement theory have been recently applied in intellectual capital measurement. It has been suggested that these elements should serve as the basis for developing, reasoning and applying intellectual capital measures.

Pike et al. (2001) are probably among the first who applied measurement theory to intellectual capital measurement. They argued that basing measurement systems on the canonical requirements of measurement theory provides a means by which nonfinancial based measurement systems can achieve the same (or better) degrees of rigor as financially based ones. They further maintained that according to measurement theory, there are 13 requirements for a measurement system. However, Pike and Roos (2004) suggested only five conditions for a business measurement scheme capable of measuring business performance.

\section{Reasearch and methodology}

Based on the underlying theoretical framework and the previous literature linking intellectual capital with a firm's success, we have attempted to develop testable hypotheses. The hypotheses in this study explore the relationship between human, structural, physical capital and income smoothing and stock return.

Bontis (1998) found a significant relationship between each element of IC and firms' performance. Several financial measures such as profit, profit growth, sales growth and ROI were used as indicators of a firm's performance. The results of Bontis' (1998) study also indicated that although each element of IC has a significant relationship with a firm's performance, there are also significant associations between IC elements.

Many researchers (Chen et al., 2005; Firer \& Williams, 2003; Riahi-Belkaoui, 2003) have argued that if the market is efficient, investors will put a higher value on the firms with greater intellectual capital. Furthermore, Chen et al., (2005) maintained that if intellectual capital is a valuable resource for a firm's competitive advantage, it will contribute to a firm's financial performance.

Using Taiwanese listed companies and applying VAIC intellectual coefficients, Chen et al. (2005) found that human capital and structural capital have a positive impact on a firm's financial performance and its market value. 
So our hypotheses are:

H1: Physical capital and income smoothing are associated

H2: Human capital and income smoothing are associated

H3: Structural capital and income smoothing are associated

H4: Physical capital and stock return are associated

H5: Human capital and stock return are associated

H6: Structural capital and stock return are associated

\section{Sampling and Data Collection Procedures}

The data for the current study has been obtained from archival sources of Tehran Stock Exchange. The database has been extensively used in the accounting literature and included data on approximately 108 firms-years. All medicinal companies with available annual data in the database were selected. The crosssectional data coverage ranges from 2006 to 2011.

\section{Results}

Table 1 contains descriptive statistics for all the variables used in our study. As it can be observed from Table 1, the valid number of observations for each variable is 108 firm-years. Mean, median, and standard deviation are reported for each variable used in the current study. Table 2 contains descriptive statistics for each variable in each year. Analyzing the median for the sample period does not indicate any observable trend in the variables used for the current study.

Table $1 \mathrm{~N}$ Mean Median Std. Deviation

\begin{tabular}{|c|c|c|c|c|c|}
\hline \multicolumn{6}{|c|}{ Residuals Statistics (Dependent variable: income smoothing) } \\
\hline & Minimum & Maximum & Mean & Std. Deviation & $\mathrm{N}$ \\
\hline Predicted Value & 0.67067891 & 2.54667234 & 0.85138798 & 0.260689333 & 108 \\
\hline Residual & -1.13228941 & 1.66726244 & 0.00000000 & 0.521694530 & 108 \\
\hline Std. Predict. Value & -0.693 & 6.503 & 0.000 & 1.000 & 108 \\
\hline Std. Residual & -2.140 & 3.151 & 0.000 & 0.986 & 108 \\
\hline \multicolumn{6}{|c|}{ Residuals Statistics (Dependent variable: stock return) } \\
\hline & Minimum & Maximum & Mean & Std. Deviation & $\mathrm{N}$ \\
\hline Predicted Value & 9.531609 & 70.328079 & 39.072412 & 11.6781320 & 108 \\
\hline Residual & -103.2124634 & 188.7416840 & 0.0000000 & 51.2422323 & 108 \\
\hline Std. Predict. Value & -2.530 & 2.676 & 0.000 & 1.000 & 108 \\
\hline Std. Residual & -1.986 & 3.631 & 0.000 & 0.986 & 108 \\
\hline
\end{tabular}

Source: author's calculation 
Table 2 Descriptive Statistics

\begin{tabular}{|c|c|c|c|c|c|c|}
\hline \multicolumn{7}{|c|}{ Coefficients (Dependent variable: income smoothing) } \\
\hline & \multirow[t]{2}{*}{ Model } & \multicolumn{2}{|c|}{$\begin{array}{l}\text { Unstandardized } \\
\text { Coefficients }\end{array}$} & \multirow{2}{*}{\begin{tabular}{|c}
$\begin{array}{c}\text { Standardized } \\
\text { Coefficients }\end{array}$ \\
Beta \\
\end{tabular}} & \multirow[t]{2}{*}{$\mathbf{T}$} & \multirow[t]{2}{*}{ Sig. } \\
\hline & & B & Std. Error & & & \\
\hline \multirow{4}{*}{1} & (Constant) & 3.191 & 0.536 & & 5.959 & 0.000 \\
\hline & $\begin{array}{c}\text { capital } \\
\text { employed } \\
\text { Coefficient }\end{array}$ & -0.142 & 0.463 & -0.030 & -0.306 & 0.760 \\
\hline & $\begin{array}{c}\text { human capital } \\
\text { Coefficient }\end{array}$ & 0.035 & 0.025 & 0.134 & 1.392 & 0.167 \\
\hline & $\begin{array}{c}\text { structural capital } \\
\text { Coefficient }\end{array}$ & -0.845 & 0.570 & -0.143 & -1.483 & 0.141 \\
\hline \multicolumn{7}{|c|}{ Coefficients (Dependent variable: stock return) } \\
\hline & \multirow[t]{2}{*}{ Model } & \multicolumn{2}{|c|}{$\begin{array}{l}\text { Unstandardized } \\
\text { Coefficients }\end{array}$} & \begin{tabular}{|} 
Standardized \\
Coefficients
\end{tabular} & \multirow[t]{2}{*}{$\mathbf{T}$} & \multirow[t]{2}{*}{ Sig. } \\
\hline & & B & Std. Error & Beta & & \\
\hline \multirow{4}{*}{1} & (Constant) & -1.795 & 52.605 & & -0.034 & 0.973 \\
\hline & $\begin{array}{c}\text { capital } \\
\text { employed } \\
\text { Coefficient }\end{array}$ & 87.447 & 41.380 & 0.203 & 2.113 & 0.037 \\
\hline & $\begin{array}{l}\text { human capital } \\
\text { Coefficient }\end{array}$ & 1.582 & 3.863 & 0.066 & 0.409 & 0.683 \\
\hline & $\begin{array}{c}\text { structural capital } \\
\text { Coefficient }\end{array}$ & 4.191 & 86.990 & 0.008 & 0.048 & 0.962 \\
\hline
\end{tabular}

Source: author's calculation

\section{Correlations}

The correlations among variables used in the study were determined. The correlations among all three variables used to measure IC were statistically significant $(p<0.05)$.

\section{Results for the hypotheses test}

After investigating the overall model fit and loadings of individual variables into the defined constructs with SPSS, six research hypotheses were tested as follows: 


\section{Hypothesis 1}

It was hypothesized that Physical Capital is associated with income smoothing. According to the results, Physical Capital is not associated with income smoothing (Unstandardized coefficient $=-0.142$, Sigt $=-0.760, \mathrm{p}<0.05$ ), reaching significance, and therefore Hypothesis 1 was not supported.

\section{Hypothesis 2}

According to this hypothesis, human capital is associated with income smoothing. Based on the results, investment in human capital cannot be positively associated with income smoothing.

(Unstandardized coefficient $=0.035$, Sigt $=0.167, \mathrm{p}<0.05$ ), reaching significance, and therefore Hypothesis 2 was not supported.

\section{Hypothesis3}

It was hypothesized that structural capital can positively predict income smoothing. The results indicate that structural capital cannot positively predict income smoothing

(Unstandardized coefficient $=-0.845$, Sigt $=-0.141, \mathrm{p}<0.05)$. Therefore, we did not find evidence to support Hypothesis 3.

\section{Hypothesis 4}

It was hypothesized that Physical Capital is associated with stock return. According to the results, Physical Capital is associated with stock return.

(Unstandardized coefficient $=87.447$, Sigt $=0.037, \mathrm{p}<0.05$ ), reaching significance, and therefore Hypothesis 4 was supported.

\section{Hypothesis 5}

According to this hypothesis, human capital is associated with stock return. Based on the results, investment in human capital cannot be positively associated with stock return.

(Unstandardized coefficient $=1.582$, Sigt $=0.683, \mathrm{p}<0.05$ ), reaching significance, and therefore Hypothesis 5 was not supported.

\section{Hypothesis 6}

It was hypothesized that structural capital can positively predict stock return. The results indicate that structural capital cannot positively predict stock return.

(Unstandardized coefficient $=4.191$, Sigt $=0.962, \mathrm{p}<0.05)$. Therefore, we did not find evidence to support Hypothesis 6. 
The results show that all variables used to measure IC are not associated with income smoothing. It means some other variables affect income smoothing. High or low intellectual capital is not incentive for a company for income smoothing. Also results show Physical Capital is associated with stock returns. It means that a company with higher Physical Capital can achieve higher stock returns. But only investment in human capital and structural capital cannot lead to higher stock returns.

\section{Conclusions}

\section{Summary and Discussion of the Findings}

The extant literature in the area of intellectual capital provides support for the interconnections of IC components. In a recent study using a sample of Canadian and Middle Eastern companies, Nazari et al. (2009) found positive and significant correlations among organizational, human, and relational capital. Some other recent studies (for example see Herremans, Isaac, Kline, \& Nazari, 2010) do not even separate the components of IC and use an aggregate IC construct due to the high inter correlations among the IC components.

The results show that in order to utilize IC effectively, there should be a significant interaction among the components of intellectual capital. As discussed in the theoretical part of the study, the isolated knowledge that exists in the minds of employees would not be useful to the organization unless this knowledge is codified and put in practice to leverage from this asset. In other words, organizations will not benefit from tacit knowledge unless they make some investments in the organizational infrastructures and communications to make this type of knowledge explicit. The results of our study did not provide support for the positive relationship between structural capital; human capital and firm's financial performance. The previous literature shows mixed results. The results of our study are not consistent with some of the earlier studies that provide evidence for this positive relationship. For example, Bontis et al. (2000), using a survey instrument and conducting PLS on a Malaysian sample, found a significant relationship between structural capital and financial performance. In another study, using a sample of Taiwanese and applying the VAIC model, Chen et al. (2005) found a significant relationship between structural capital and financial performance. Yet, there have been some other studies indicating a lack of positive relationship between structural capital, human capital and financial performance.

As stated earlier, the field of IC is not saturated and, as such, there is a lack of consensus on the measures or methods that should be used in evaluating the relationships between structural capital and performance. Few studies in the field 
of IC, some of which are mentioned above, have used different variables, different methods, and different samples in conducting their statistical analyses.

Also results show there is not any relationship between capital employed (physical capital) and income smoothing but the relationship between capital employed (physical capital) and stock return is positive.

Our research was designed to investigate the relationship between the components of IC and a firm's financial performance. Based on a wellaccepted conceptual framework it was decomposed into human and structural components. The relationship between these components and two indicators of financial performance, income smoothing and stock return was investigated.

This result has some practical implications. It denotes that in order to utilize IC more effectively, managers should establish an effective link between IC components. For example, organizations will not benefit from the knowledge in the minds of individuals unless they make some investment in organizational routines and processes that would put such knowledge in practice.

Finally, the results did not provide evidence for a positive relationship between structural capital and firm's financial performance. What has been documented in this study is that investment in organizational structures and databases, computer software, and increased advertising might not necessarily lead to improved financial performance.

The value of IC would be realized through the interaction of structural capital and human capital as these two components are highly correlated. In spite of the strong existing theoretical argument for the contribution of structural capital to firm's success, the current financial disclosures do not seem to provide a good proxy that would assist users in predicting the link between structural capital and firm's success. Future researchers need to find better proxies of structural capital than what is reported in traditional financial statements.

The results of the current study add to the growing body of literature in the field of IC by recognizing the most influential elements of intellectual capital on a firm's performance. It would help organizations to have a clearer understanding and better management of the organizational capabilities they possess. It will also help firms to identify which indicators are the better predictors of their success.

The field of IC is not yet in its maturity stage and many of the studies conducted in the field are foundational in nature. Although the VAIC model has received some attention in cross-company comparisons, the model suffers from some inherent limitations due to the unavailability of data in some contexts 
and the econometric properties of the developed model. This study used alternative variables to measure IC.

Similar to the VAIC model, the proxies used in the current study are input measures and that have the potential to be realized.

However, the input-output relationship could not be investigated due to the unavailability of such data. Similar questions can be raised about human capital proxies. The mechanisms in labor markets are such that higher value is placed on more skilled employees but the question remains if these higher paid employees are more productive.

Unfortunately, IC output measures are not publicly available yet, but investors and creditors are more aware of the increasing importance of these intangible assets. Lev (2001) questioned the value-relevance of traditional financial measures due to the increasing importance of off-the-balance sheet assets for stakeholders. Traditional financial statements report limited information about the value intangible assets.

Stakeholders are putting more pressure on companies to provide information about their intellectual capital.

Future studies are encouraged to use the data from the companies adopting the proposed framework to investigate the relationship between better developed intellectual capital proxies and firms' performance. In addition, to confirm that the patterns of results are valid over time, future studies need to replicate the model used in our study longitudinally.

Finally, due to the same limitations addressed above, our study has not explored variations across different industries. Future research may want to extend this study by looking at the variations of these intellectual capital proxies across different industries and by investigating other indicators of a firm's performance such as market value.

\section{References}

Beidleman, C. (1973). Income smoothing: The role of management. The Accounting Review, 48(4), pp. 653-667.

Boisot, M. (2002). The creation and sharing of knowledge. In C. W. Choo \& N. Bontis (Eds.), The Strategic Managment of Intellecutal Capital and Organizational Learning. Oxford: Oxford University Press.

Bontis, N. (1999). Managing organisational knowledge by diagnosing intellectual capital: framing and advancing the state of the field. International of Journal of Technology Management, 18(5), pp. 433-462. 
Bontis, N. (1996). There's a price on your head: managing intellectual capital strategically. Business Quarterly, 60(4), pp. 40-47.

Bontis, N. (1998). Intellectual capital: an exploratory study that develops measures and models. Management Decision, 36(2), pp. 63-76.

Bontis, N. (2001). Assessing knowledge assets: a review of the models used to measure intellectual capital. International Journal of Management Reviews, 3(1), pp. 41-60.

Bontis, N., Crossan, M. M. and Hulland, J. (2002). Managing An Organizational Learning System By Aligning Stocks and Flows. Journal of Management Studies, 39(4), pp. 437-469.

Chaney, P. K. and Lewis, C. M. (1995). Earnings management and firm valuation under asymmetric information. Journal of Corporate Finance, 1(3-4), pp. 319-45.

DeFond, M. L. and Park, C. W. (1997). Smoothing income in anticipation of future earnings. Journal of Accounting and Economics, 23, pp. 115-139.

Edvinsson, L., \& Malone, M. S. (1997). Intellectual Capital: Realizing Your Company's True Value by Finding Its Hidden Brainpower. New York: HarperBusiness.

Edvinsson, L., \& Sullivan, P. (1996). Developing a model for management intellectual capital. European Management Journal, 14(4), 187-199.

Francis, J., R. LaFond, P. Olsson, and K. Schipper. 2004. "Costs of Equity and Earnings Attributes." The Accounting Review, 79, pp. 967-1010.

Graham, J. R., C. R. Harvey and Rajgopal, S. (2005). The economic implications of corporate financial reporting. Journal of Accounting and Economics, 40, pp. 373.

Gu, Z., and Zhao, J. Y. (2006). Information precision and the cost of debt. Working paper, Carnegie Mellon University.

Jamal Aldin Nazari (2010). An Investigation of the Relationship between the Intellectual Capital Components and Firm's Financial Performance.

LaFond, R., M. Lang, and Ashbaugh-Skaife, H. (2007). Earnings smoothing, governance and liquidity: International evidence. Working paper.

Leuz, C., D. Nanda, and Wysocki, P. (2003). Investor protection and earnings management. Journal of Financial Economics, 69(3), pp. 505-527.

Luthy, D. H. (1998). Intellectual capital and its measurement. Paper presented at the Asian Pacific Interdisciplinary Research.

Marr, B., Gray, D. and Neely, A. (2003). Why do firms measure their intellectual capital? Journal of Intellectual Capital, 4(4), pp. 441-464.

Marti, J. M. V. (2001). ICBS - intellectual capital benchmarking system. Journal of Intellectual Capital, 2(2), pp. 148-165. 
McPherson, P. K. and Pike, S. (2001). Accounting, empirical measurement and intellectual capital. Journal of Intellectual Capital, 2(3), pp. 246-260.

Ordonez de Pablos, P. (2004). Measuring and reporting structural capital: Lessons from European learning firms. Journal of Intellectual Capital, 5(4), pp. 629-647.

Pike, S. and Roos, G. (2004). Mathematics and modern business management. Journal of Intellectual Capital, 5(2), pp. 243-256.

Pike, S., Rylander, A., and Roos, G. (2001). Intellectual capital management and disclosure. Paper presented at the 4th World Congress on Intellectual Capital, McMaster University, Hamilton.

Pulic, A. (1998, 1998). Measuring the performance of intellectual potential in Knowledge Economy. Paper presented at the 2nd World Congress on Measuring and Managing Intellectual Capital, McMaster University, Hamilton.

Pulic, A. (2000). VAIC ${ }^{\mathrm{TM}}$-an accounting tool for IC management. International Journal of Technology Management, 20(5/6/7/8), pp. 702-714.

Ronen, J. and S. Sadan. 1981. Smoothing Income Numbers: Objectives, Means and Implications. Reading, MA: Addison Wesley.

Roos, J., Roos, G., Dragonetti, N. C., \& Edvinsson, L. (1998). Intellectual Capital: Navigating in the New Business Landscape. New York: New York University Press.

Saint-Onge, H. (1996). Tacit knowledge: the key to the strategic alignment of intellectual capital. Strategy \& Leadership, 24(2), pp. 10-14.

Stewart, T. A. (1991). Brainpower: intellectual capital is becoming corporate America's most valuable asset and can be its sharpest competitive weapon; the challenge is to find what you have - and use it. Fortune, 123(11), pp. 44-60.

Stewart, T. A. (1997). Intellectual capital: the new wealth of organizations. New York, NY, USA: Doubleday.

Sveiby, K. E. (1997b). The New Organizational Wealth: Managing and Measuring Knowledge-Based Assets. San Francisco, CA: Berrett-Koehler Publishers.

Sveiby, K. E. (2007). Methods for Measuring Intangible Asset. From http://www.sveiby.com/Portals/0/articles/IntangibleMethods.htm.

Subramanyam, K. R. (1996). The pricing of discretionary accruals. Journal of Accounting and Economics, 22, pp. 249-281.

Tucke,r J. and Zarowin, P. (2006). Does Income Smoothing Improve Earnings informativeness? The Accounting Review, 81(1), pp. 251-270.

Walsh, J. P. and Ungson, G. R. (1991). Organizational Memory. The Academy of Management Review, 16(1), pp. 57-91. 